\title{
ANALISIS PENERAPAN MODEL PEMBELAJARAN KOOPERATIF NUMBERED HEAD TOGETHER (NHT) DAN PENGARUHNYA TERHADAP HASIL BELAJAR SISWA PADA MATERI STRUKTUR ATOM DI KELAS X SMKN 3 KOTA JAMBI
}

\author{
M. Dwi Wiwik Ernawati ${ }^{1}$, Haryanto $^{2}$ dan Setia CP Nababan ${ }^{3}$ \\ Jurusan Pendidikan MIPA FKIP Universitas Jambi, Kampus Pinang Masak, Jambi, \\ Indonesia \\ 1email:dwi.wiwik@unja.ac.id \\ 2email: Haryanto.fkip@unja.ac.id \\ 3 email: setianababan3@gmail.com
}

\begin{abstract}
ABSTRAK
Telah dilakukan penelitian yang dilaksanakan di SMKN 3 Kota jambi, pembelajaran kimia di sekolah ini hanya berjalan satu arah, sehingga siswa hanya mencatat dan mendengarkan penjelasan guru. Untuk itu dibutuhkan model pembelajaran yang dapat mengaktifkan siswa, salah satunya yaitu model pembelajaran tipe NHT.

Penelitian ini bertujuan untuk mengetahui sejauh mana keterlaksanaan model NHT serta pengaruhnya terhadap hasil belajar siswa pada materi struktur atom di SMKN 3 Kota Jambi.

Jenis penelitian ini adalah quasi eksperimen dengan desain one shot case study. Teknik pengambilan sampel dilakukan dengan teknik Simple Random Sampling. Terdapat satu kelas yang digunakan sebagai sampel yaitu kelas XAV . Instrumen penelitian berupa lembar observasi keterlaksanaan NHT baik dari guru maupun siswa dan hasil belajar siswa. Pengaruh keterlaksanaan model NHT dengan hasil belajar siswa dicari dengan pearson product moment. Untuk melihat signifikansi keterlaksanaan model NHT terhadap hasil belajar siswa digunakan uji-t.

Keterlaksanaan model NHT oleh guru dan siswa dikategorikan baik yang terlihat dari rata-rata tiap pertemuannya. keterlaksanaan model NHT dengan hasil belajar dikategorikan sedang dengan rata-rata $\mathrm{r}$ 0,564 dan terdapat pengaruh keterlaksanaan model NHT dengan hasil belajar siswa pada thitung 3,965 dengan signifikansi 3,965< 2,02 .

Model NHT dalam pembelajaran struktur atom di kelas X SMKN 3 Kota Jambi terlaksana dengan baik oleh guru dengan melibatkan siswa dalam proses pembelajaran sehingga hasil belajar siswa dapat meningkat. Terdapat pengaruh pelaksanaan model NHT terhadap hasil belajar siswa dalam pembelajaran struktur atom di kelas X SMKN 3 Kota Jambi.
\end{abstract}

Kata Kunci : Model Numbered Head Together (NHT), Hasil Belajar, Struktur Atom.

\section{ABSTRACT}

Have done there search implemented in SMK n 3 Kota jambi, learning chemistry in this school only run sone direction, so that the students only take notes and listen to 
the teacher's explanations. For that it needs a learning model that can enable students, one of which is the learning model type NHT.

This research aims to determine the extent of adherenceto model NHT and its influence on student learning outcomes in the material structure of the atom in SMKN 3 Jambi.

This type of research is quasi experiment with design one shot case study. The technique of sampling was done by Simple Random Sampling technique. There is one class used as the sample, namely the class of XAV. Research instruments observation sheet the feasibility NHT better than the teacher and the student and student learning outcomes.

The influence of adherence to a model of NHT with the students learning outcomes sought by the pearson product moment. To see the significance of the adherence model of the NHT against the learning outcomes of the student t-test.

The feasibility model of the NHT by the teacher and students good categorized that looks than the average every meeting. feasibility model of NHT with the results of

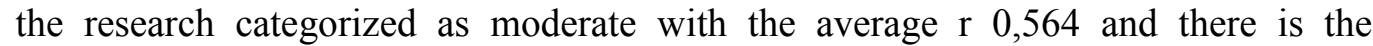
influence of adherence to a model of NHT with the student learning outcomes on the t 3,965 with significance $3,965<2,02$.

Model NHT in learning atomic structure in class X SMKN 3 Jambi implemented well by teachers to involve students in the learning process so that student learning outcomes can be increased. There is the influence of the implementation of the model of the NHT against the learning outcomes of students in learning atomic structure in class X SMKN 3 Jambi.

Keywords : Model Numbered Head Together (NHT), Learning Outcomes, Structure of the Atom 


\section{PENDAHULUAN}

Pendidikan merupakan kegiatan yang berintikan interaksi antara peserta didik dengan para pendidik serta berbagai sumber pendidikan $^{3)}$. Pendidikan juga merupakan faktor yang sangat penting dalam pembangunan bangsa dan negara. Oleh karena itu dunia pendidikan dituntut untuk lebih meningkatkan mutu dan kualitas pendidiknya seiring dengan perkembangan ilmu pengetahuan dan teknologi di era globalisasi yang semakin hari semakin maju. Pendidikan merupakan suatu kebutuhan yang diperlukan setiap manusia agar dapat mengembangkan kemampuan, bakat dan potensi yang dimilikinya. Ada beberapa faktor yang mempengaruhi keberhasilan pendidikan diantaranya seperti: guru, siswa, sarana, prasarana, lingkungan pendidikan, serta kurikulum. Guru menempati kedudukan yang sangat penting tanpa mengabaikan faktor penunjang yang lain. Guru dituntut untuk memiliki kreativitas dalam hal mendidik dan mengajar siswanya agar tercapai tujuan pembelajaran.

Pendidikan juga bisa diartikan sebagai kegiatan yang disengaja atas input siswa untuk menimbulkan suatu hasil yang diinginkan sebagai tujuan yang ditetapkan. Sebagai sebuah proses yang disengaja maka pendidikan harus dievaluasi hasilnya untuk melihat apakah hasil yang dicapai telah sesuai dengan tujuan yang diinginkan dan apakah proses yang dilakukan efektif untuk mencapai hasil yang diinginkan (Purwanto, 2007).

Pelajaran kimia tentang struktur atom tidak seperti materi kimia lainnya. Materi struktur atom tidak dapat mengembangkan kemampuan eksperimen siswa karena materi struktur atom kebanyakan berisi tentang pemahaman konsep, teori-teori dan ketentuan-ketentuan dari para ahli kimia. Materi struktur atom termasuk materi yang abstrak karena siswa hanya bisa mempelajari tanpa dapat melihat bagaimana bentuk dari struktur atom tersebut. akibatnya siswa sulit memahami dan mempelajari materi tersebut.

Berdasarkan hasil observasi dan program pengalaman lapangan (PPL) di SMKN 3 Kota Jambi yang dilakukan di kelas X pada tahun ajaran 2015/2016, diketahui dalam kegiatan belajar mengajar interksi siswa dan guru hanya berjalan satu arah, yaitu guru yang berperan aktif, kebanyakan siswa hanya mendengarkan dan mencatat tanpa memahami materi pelajaran yang disampaikan oleh guru. Hal ini berdampak pada hasil ulangan siswa pada materi struktur atom menunjukkan sebagian besar siswa tidak mencapai nilai ketuntasan. Untuk persentase nilai siswa yang lulus dan yang tidak lulus 
pada materi struktur atom adalah $40 \%$ dan $60 \%$. Nilai ketuntasan pada materi kimia di SMKN 3 Kota Jambi adalah 70.

Masih rendahnya kualitas belajar siswa dapat diketahui dari indikator kualitas proses dan hasil belajar. Kualitas proses pembelajaran dapat diamati dari bagaimana aktivitas siswa, interaksi guru-siswa, dan motivasi belajar siswa. Sedangkan kualitas hasil belajar dapat diamati dari prestasi belajar dan ketuntasan belajar siswa.

Informasi yang didapat dari guru kimia di SMKN 3 Kota Jambi diketahui beberapa penyebab permasalahan yang terjadi dalam proses pembelajaran pada materi struktur atom: (1) selama proses kegiatan belajar mengajar berlangsung siswa hanya

mencatat dan mendengarkan penjelasan dari guru, (2) selama proses kegiatan belajar mengajar berlangsung hanya sebagian siswa yang aktif bertanya dan menjawab pertanyaan dari guru, (3) sebagian besar siswa kurang memperhatikan pelajaran, terbukti mereka banyak yang bicara dengan teman sebangku dan ada yang mengantuk. Keadaan seperti ini kemungkinan timbul karena siswa mengalami kejenuhan terhadap metode pembelajaran yang berpusat pada guru.

Salah satu cara yang dapat digunakan untuk meningkatkan hasil belajar siswa adalah dengan menggunakan model pembelajaran kooperatif. Model pembelajaran kooperatif merupakan suatu model pembelajaran yang mengutamakan adanya kelompok-kelompok. Setiap siswa yang ada dalam kelompok mempunyai tingkat kemampuan yang berbeda-beda dan jika memungkinkan anggota kelompok bersal dari ras, budaya, suku yang berbeda serta memperhatikan kesetaraan gender. Model pembelajaran kooperatif mengutamakan kerjasama dalam menyelesaikan permasalahan untuk menerapkan pengetahuan dan keterampilan dalam rangka mencapai tujuan pembelajaraan. Pembelajaran kooperatif memberikan kesempatan kepada siswa untuk mengembangkan potensi yang ada dalam dirinya, belajar dari teman, belajar bertukar pendapat, belajar bertanggung jawab pada orang lain dan kelompok, belajar mengambil suatu sikap atau keputusan. Pada prinsipnya pembelajaran ini juga dapat meningkatkan kemampuan siswa untuk berdikusi. Dengan adanya kelompok belajar, maka akan terjadi interaksi antara siswa dengan sesamanya ataupun siswa siswa dengan guru, sehingga dapat menjadikan siswa berperan aktif dalam pembelajara (Hosnan 2014).

Menurut $^{5)}$ ada beberapa tipe dari model pembelajaran kooperatif, diantaranya yaitu Think Pair

Share (TPS), Numbered Heads Together (NHT), Student Teams- 
Achievement Divisions (STAD), Jigsaw (Model Tim Ahli), Group Investigation. Numbered Heads Together (NHT) atau penomoran berpikir bersama adalah merupakan jenis pembelajaran kooperatif yang direncang untuk mempengaruhi pola interaksi siswa dan sebagai alternatif terhadap struktur kelas tradisional. Model pembelajaran ini memberikan kesempatan kepada siswa untuk saling berbagi ide dengan seluruh anggota kelompoknya dan dapat mempertimbangkan jawaban yang paling tepat untuk menjawab pertanyaan atau memecahkan permasalahan yang diberikan guru (Trianto, 2009). Model pembelajaran tipe NHT merupakan salah satu tipe pembelajaran kooperatif yang menekankan pada struktur khusus yang dirancang untuk mempengaruhi pola interaksi siswa dan memiliki tujuan untuk meningkatkan hasil belajar siswa. Tercapainya tujuan pembelajaran dan keefektifan pembelajaran tergantung pada bagaimana guru mampu melakukan aktivitas mengajar secara baik dengan menggunakan model dan strategi yang tepat (Sagala, 2012). Hasil belajar adalah kemampuan-kemampuan yang nampak setelah menempuh pengalaman belajar (Sudjana, 2006). Hasil belajar yang dicapai oleh siswa merupakan alat untuk mengukur sejauh mana siswa menguasai materi pelajaran yang diajarkan.

Berdasarkan uraian di atas, maka penulis tertarik untuk melakukan penelitian yang berjudul "Analisis Penerapan Model Pembelajaran Kooperatif Numbered Head Together (NHT) dan Pengaruhnya Terhadap Hasil Belajar Siswa pada Materi Struktur Atom di Kelas X SMKN 3 Kota Jambi”.

\section{METODE PENELITIAN}

Berdasarkan permasalahan yang diteliti, maka jenis penelitian ini merupakan penelitian eksperimen semu (quasi-eksperimen). Penelitian ini bertujuan untuk mengungkapkan hubungan sebab akibat antara variabel bebas keterlaksanaan model NHT dan variabel terikat yaitu hasil belajar siswa.

Dengan rancangan penelitian menggunakan One Shot-Case Study yaitu melakukan pengamatan terhadap guru dan siswa pada setiap pertemuan dan melakukan posttest untuk melihat hasil belajarnya (Sugiyono, 2013). Dalam penelitian ini hanya satu kelas yang diteliti sebagai kelas eksprimen. Kelas eksprimen diambil secara simple random sampling yaitu pengambilan sampel secara undian dari populasi. Dikelas eksperimen inilah dilakukan observasi keterlaksanaan model NHT tiap pertemuan dengan melihat aktivitas guru dan siswa oleh observer dengan menggunakan lembar observasi sehingga diperoleh data kuantitatif baik aktivitas guru maupun aktivitas siswa kemudian data kuantitatif aktivitas guru 
dan siswa yang diperoleh di analisis dengan menggunakan rata-rata setelah itu kedua data kuantitatif aktivitas guru dan siswa diuji kesamaan dua rata-rata kemudian data dideskripsi sehingga diperoleh keterlaksanaan model NHT. Untuk melihat hasil belajar siswa dilakukan posttest menggunakan instrument kognitif berupa pilihan ganda diperoleh data kuantitatif. Untuk melihat hubungan keterlaksanaan model NHT terhadap hasil belajar data hasil observasi keterlaksanaan model NHT aktivitas siswa dikorelasikan dengan data hasil belajar dengan menggunakan korelasi product moment pearson selanjutnya untuk melihat pengaruh dilakukan uji lanjut dengan uji t.

\section{HASIL DAN PEMBAHASAN}

\section{Keterlaksanaan model NHT}

1. Hasil observasi keterlaksanaan model

NHT oleh guru

Data keterlaksanaan model oleh guru diperoleh dari hasil observasi oleh 1 orang observer. Berikut diagram persentasenya:

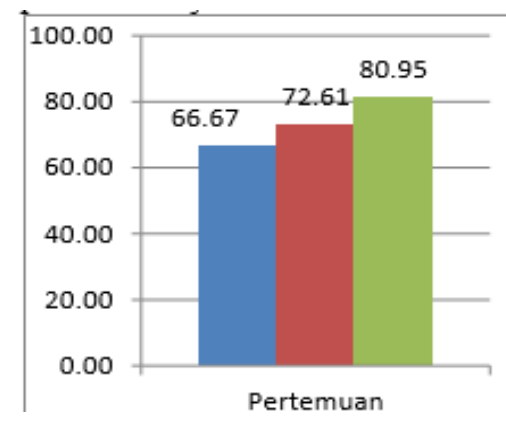

Berdasarkan diagram diatas, pelaksanaan NHT oleh guru mengalami peningkatan jumlah persentase Pada pertemuan pertama model NHT terlaksana sebesar $66,67 \%$ yang terkategori baik. Pada pertemuan kedua terjadi peningkatan persentase sebesar 5,94\% menjadi 72,61\% terkategori baik dan pada pertemuan ketiga juga demikian dengan peningkatan persentase sebesar $8,3 \%$ menjadi 80,95\% dengan kategori baik. Rata-rata persentase dari ketiga pertemuan yakni $73,4 \%$ dengan kategori baik.

2. Hasil observasi keterlaksanaan model NHT oleh siswa

Hasil persentase keterlaksanaan NHT terbimbing oleh siswa diamati oleh 5 orang observer. Berikut diagram persentase keterlaksanaan model oleh siswa:

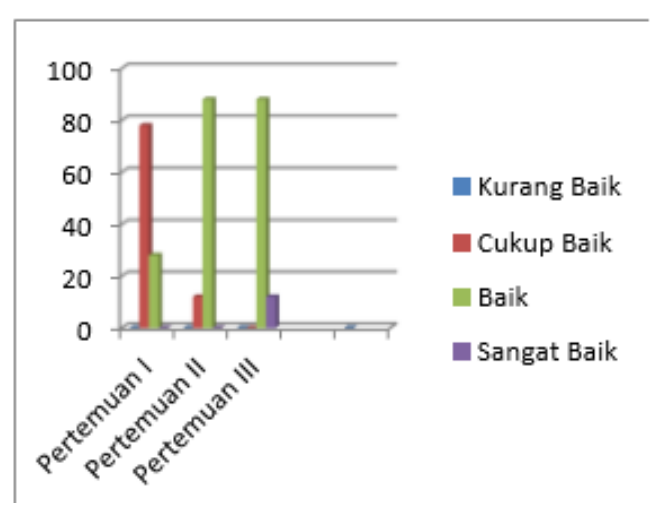

Dari tabel dapat dilihat bahwa terdapat perbedaan hasil lembar observasi tiap pertemuan. Keterlaksanaan model NHT dari hasil lembar observasi ini dikategorikan ke dalam empat kategori yakni kurang baik, cukup baik, baik dan sangat baik. Untuk kategori kurang baik tidak ada siswa yang mendapatkan nilai total antara rentang 16-28. Lalu untuk kategori cukup baik, pada pertemuan pertama 
didapat 18 siswa yang mendapat total rentang $29-41$ sehingga didapat persentasenya $72 \%$. Kemudian untuk pertemuan kedua didapat 3 siswa dengan persentase $12 \%$. Pada pertemuan ketiga, tidak ada siswa yang berkategori cukup baik.

Selanjutnya untuk kategori baik dengan rentang nilai antara 42-54 pada pertemuan pertama diperoleh sebanyak 7 siswa dengan persentase 28\%. Pada pertemuan kedua diperoleh sebanyak 22 siswa dengan persentase $88 \%$. Kemudian pada pertemuan ketiga diperoleh sebanyak 22 siswa dengan persentase $88 \%$.

Kategori yang terakhir yakni sangat baik dengan rentang nilai $\leq 55$, pada pertemuan pertama dan kedua tidak ada siswa yang mendapat kategori tersebut. Untuk pertemuan ketiga diperoleh 3 siswa dengan persentase $12 \%$.

\section{Hasil belajar siswa}

Data hasil belajar siswa diperoleh dari tes kognitif yang berupa soal objektif yang diberikan sesudah proses pembelajaran (posttest). Soal-soal yang digunakan adalah soal-soal tes objektif yang telah divalidasi dan sudah memenuhi kriteria validitas, daya beda, tingkat kesukaran dan reliabilitas.

Hasil dari soal-soal yang diberikan kepada kelas sampel tersebut dilakukan analisis data untuk melihat hasil belajar yang dicapai.

\begin{tabular}{|c|l|c|}
\hline No. & Keterangan & Perolehan \\
\hline 1. & Nilai terendah & 56 \\
\hline 2. & Nilai tertinggi & 96 \\
\hline 3. & Nilai rata-rata kelas & 76,32 \\
\hline 4. & Jumlah siswa yang tuntas & 18 siswa \\
\hline 5. & $\begin{array}{l}\text { Jumlah siswa yang belum } \\
\text { tuntas }\end{array}$ & 7 siswa \\
\hline 6. & Persentase ketuntasan & $72 \%$ \\
\hline
\end{tabular}

\section{Pengujian hipotesis}

Hubungan yang akan dilihat adalah keterlaksanaan model NHT dengan hasil belajar siswa. Uji hipotesis dilakukan dengan mencari korelasi dengan menggunakan rumus korelasi product moment antara keterlaksanaan model NHT dengan hasil belajar siswa. Dari perhitungan koefisien korelasi (r) dari kedua variabel tersebut, diperoleh nilai (r) 0,564. Berdasarkan tabel pedoman interpretasi koefisien korelasi (tabel 3.11) nilai r 0,564 berada pada interval 0,40-0,599 (Sugyono, 2013), dengan demikian hubungan antara keterlaksanaan model pembelajaran NHT dengan hasil belajar siswa pada penelitian ini memiliki tingkat hubungan sedang. Nilai korelasi (r) berkisar antara variabel semakin kuat, sebaliknya nilai mendekati 0 berarti hubungan antara 2 variabel semakin lemah. Hal ini berarti hipotesis $\mathrm{H}_{\mathrm{a}}$ dapat diterima karena $0<\mathrm{r} \leq 1$ yang menunjukkan terdapat hubungan antara keterlaksanaan model NHT dengan 
hasil belajar siswa pada materi struktur atom di kelas X SMK N 3 kota jambi.

\section{Korelasi antara keterlaksanaan model NHT dengan hasil belajar siswa}

Setelah diperoleh hasil skor dan persentase dari lembar observasi keterlaksanaan model NHT dan hasil belajar siswa, maka dapat diketahui tingkat hubungan keduanya. Berdasarkan hasil uji korelasi product moment, didapatkan nilai $\mathrm{r}_{\mathrm{xy}}$ yaitu 0,53 yang jika diinterpretasikan memiliki tingkat hubungan yang sedang. Hal ini dapat diartikan bahwa hubungan antara keterlaksanaan model NHT terhadap hasil belajar siswa memiliki tingkat hubungan yang sedang.

Penelitian yang dilakukan oleh Wijayati (2011) mengatakan bahwa penggunaan model pembelajaran NHT dapat meningkatkan hasil belajar siswa. Demikian juga dengan Amik (2012) metode pembelajaran kooperatif tipe NHT dengan media kartu pintar dan kartu soal efektif untuk meningkatkan hasil belajar siswa. Hasil belajar siswa merupakan tujuan akhir dilaksanakannya kegiatan pembelajaran di sekolah. Hasil belajar dapat ditingkatkan melalui usaha sadar yang dilakukan secara sistematis mengarah kepada perubahan positif yang kemudian disebut sebagai proses belajar. Akhir dari proses belajar adalah perolehan suatu hasil belajar siswa. Hasil belajar siswa dikelas terkumpul dalam himpunan hasil belajar kelas. Semua hasil belajar tersebut merupakan hasil dari suatu interaksi tindak belajar dan tindak mengajar. Dari sisi guru, tindak mengajar diakhiri proses evaluasi hasil belajar, sedangkan dari sisi siswa, hasil belajar merupakan puncak proses belajar (Mujiono, 2013).

$$
\text { Berdasarkan perhitungan, }
$$
diperoleh $0<\mathrm{r} \leq 1$ sehingga $h_{a}$ diterima. Hal ini dapat menguji kebenaran hipotesis, yaitu terdapat pengaruh antara keterlaksanaan model pembelajaran NHT dengan hasil belajar siswa pada materi struktur atom di kelas X SMKN 3 kota Jambi.

Dalam pelaksanaan model pembelajaran tipe NHT ini, siswa dikelompokkan dengan diberi nomor dan setiap nomor diberi tugas berbeda dan nantinya dapat bergabung dengan kelompok lain yang bernomor sama untuk bekerja sama. Model pembelajaran tipe NHT ini bisa meningkatkan keaktifan siswa, karena masing-masing siswa bertanggung jawab terhadap tugasnya. Model pembelajaran NHT ini juga bisa menciptakan suasana belajar yang menyenangkan dan membuat siswa tidak merasa tertekan (Ibrahim, 2000).

\section{KESIMPULAN}

Berdasarkan hasil penelitian yang telah dilakukan, maka diperoleh beberapa kesimpulan penelitian, yaitu Keterlaksanaan model NHT pada materi struktur atom di kelas X SMK N 3 kota 
Jambi dikategorikan terlaksana dengan baik oleh guru maupun siswa, sesuai dengan kriteria yang telah dirancang. Terdapat pengaruh signifikan keterlaksanaan model NHT dengan hasil belajar siswa pada materi struktur atom di kelas X SMK N 3 kota Jambi.

\section{DAFTAR RUJUKAN}

1. Sudarmo, 2013. Kimia Untuk SMA Kelas $X$. Jakarta: Erlangga

2. Sudjana. 2006. Pengantar Evaluasi Pendidikan. Bandung: Raja Grafindo Persada.

3. Sugandi. 2002. Belajar dan Pembelajaran. Semarang : IKIP PRESS.

4. Tryana, A. 2008. Penerapan Model Pembelajaran Kooperatif Numbered HeadsTogether (NHT). Bandung : Sinar Baru.

5. Trianto. 2007. Model-Model pembelajaran Inovatif Berorientasi Konstruktivistik. Jakarta: Prestasi Pustaka.

6. Wijawati N, dkk. 2011. Penggunaan model pembelajaran numbered header together untuk meningkatkan hasil belajar kimia. Semarang: Jurnal.UNESS 